\title{
Zpráva z konference: „Jako muže a ženu je stvořil (Gen 1,27)“ (7. listopadu 2019, Katolická teologická fakulta, Univerzita Karlova, Praha)
}

\section{A V I D B O U A}

Dne 7. listopadu 2019 proběhla na Katolické teologické fakultě Univerzity Karlovy konference odkazující v názvu na 1. knihu Mojžíšovu s podtitulem Definice, polarita a komplementarita muže a ženy z filozofické a teologické perspektivy. Akci organizovala Katedra systematické teologie a filozofie a z tohoto pracoviště vzešli též všichni referující. Jakkoli bylo datum konání konference pro většinu referujících ještě poněkud obtížené resentimenty, od začátku př́íprav listopadového setkání bylo jasné, že $\mathrm{v}$ žádném př́padě nepůjde o pokus zaujmout nějakou pozici u barikády revolučního tématu gender či genderové teorie, ba právě naopak - že se pokusíme vnést do rozjitřené atmosféry jak v katolické církvi, tak ve společnosti pozitivní impulsy stran utváření struktur lidského světa. Konferenci zahájil vedoucí katedry doc. David Vopřada, který též moderoval první blok programu. První příspěvek přednesl hlavní organizátor konference dr. David Bouma, který nastínil hlavní teze vatikánského dokumentu věnovanému dialogu v otázce genderové výchovy („Male and Female He Created them" Towards a Path of Dialogue on the Question of Gender Theory in Education). Text Kongregace pro katolickou výchovu z 2. února 2019 určený především pro recepci ve vzdělávacích institucích ocenil referující jako vyvážený text, který vychází z auditus temporis, pokračuje racionální argumentací a vrcholí pokusem o pozitivní vizi člověka zakotveného $\mathrm{v}$ rodině a společnosti. Dokument se přimlouvá za jakousi kulturu lidské blízkosti, jež omezuje izolaci člověka $\mathrm{v}$ atomizovaném světě a vede $\mathrm{k}$ jeho komplexnímu - tělesně duševnímu rozvoji. Vychovatel má být pak schopen vnímat výzvy současnosti jako přiležitosti a vést svěřené osoby navzdory jistým ideologickým a banalizačním tlakům k utváření života do podoby sebedarování až k jeho vrcholu v manželství. Referující upozornil na skutečnost, že cílem vatikánského dokumentu je připomenout, že církev se těší ze svého evangeliem inspirovaného pohledu na člověka a chce nabízet jeho objevení prostřednictvím křestanské pedagogiky. Doprovázení mladého člověka - deklaruje text - se má dít $\mathrm{v}$ atmosféře otevřenosti, respektu a vlídnosti, bez jakékoliv diskriminace. Závěr dikasterního poselství povzbuzuje vychovatele $\mathrm{k}$ lásce $\mathrm{k}$ mladým lidem a vyjadřuje vděčnost těm, kdo „učí mladé lidi otevřenosti k druhým jakožto tváři, k osobě, jako k bratru a sestře, kdo je poznávají a respektují s jejich vlastním příběhem, zásluhami a nedostatky, přednostmi a limity. Výzvou je spolupracovat s mladými lidmi a učit je, aby byli otevření realitě, jež je obklopuje, a byli schopni péče a něhy.“ 
Následovaly příspěvky prvního bloku konference, ve kterých zazněly inspirace z děl Jacquese Maritaina (dr. Lukáš Fošum), Pavla Jevdokimova (doc. Karel Sládek) a pohled na rovnost muže a ženy z perspektivy sakramentální teologie (Benedikt Mohelník, OP). Po živé diskusi a následné přestávce převzal moderování druhého bloku konference David Bouma a uvedl referáty týkající se filozofických pojetí rovnosti pohlaví (doc. David Svoboda a dr. Prokop Sousedík), genderové spravedlnosti (dr. Petr Štica) tzv. nového feminismu (dr. Barbora Šmejdová). Hojně navštívenou a živou diskusí prostoupenou konferenci uzavíral patristickým impulsem vedoucí katedry systematické teologie a filozofie doc. David Vopřada. Na závěr bych chtěl jako organizátor konference vyjádřit svou radost z nadšených ohlasů účastníků a uspokojení, že se i ke kontroverznímu a citlivému tématu, jež si konference „Jako muže a ženu je stvořil“ zvolila, dá hovořit věcně, kompetentně, umírněně a pozitivně.

doi: 10.14712/23363398.2020.15 